Rhode Island College

Digital Commons @ RIC

\title{
Oskar Eustis and the Premiere Productions He Directed at the Trinity Repertory Company
}

\author{
Rebecca Custis \\ Rhode Island College
}

Follow this and additional works at: https://digitalcommons.ric.edu/etd

Part of the Performance Studies Commons

\section{Recommended Citation}

Custis, Rebecca, "Oskar Eustis and the Premiere Productions He Directed at the Trinity Repertory Company" (2006). Master's Theses, Dissertations, Graduate Research and Major Papers Overview. 3. https://digitalcommons.ric.edu/etd/3

This Thesis is brought to you for free and open access by the Master's Theses, Dissertations, Graduate Research and Major Papers at Digital Commons @ RIC. It has been accepted for inclusion in Master's Theses, Dissertations, Graduate Research and Major Papers Overview by an authorized administrator of Digital Commons @ RIC. For more information, please contact digitalcommons@ric.edu. 


\title{
OSKAR EUSTIS AND THE PREMIERE PRODUCTIONS HE DIRECTED AT THE TRINITY REPERTORY COMPANY
}

\author{
A Thesis Presented \\ By \\ Rebecca Custis
}

Approved:

Committee Member

Date

Committee Member

Date

Committee Member

Date

Department Chair

Date

Dean of the School of Arts and Sciences

Date 


\title{
OSKAR EUSTIS AND THE PREMIERE PRODUCTIONS HE DIRECTED AT THE TRINITY REPERTORY COMPANY
}

\author{
By \\ Rebecca Custis \\ A Thesis Submitted in Partial Fulfillment \\ of the Requirements for the Master of Arts \\ in \\ The Department of Music, Theatre, and Dance
}

The School of Arts and Sciences

Rhode Island College

2006 


\begin{abstract}
$\underline{\text { Abstract }}$
Oskar Eustis was appointed artistic director of Providence, Rhode Island's regional theatre, the Trinity Repertory Company, in 1994. He came into that position having previously successfully assisted in the dramaturgical development of significant plays as Emily Mann's Execution of Justice and Tony Kushner's Angels in America. Mr. Eustis' artistic talents center on his dramaturgical abilities in that he can select new plays with significant potential and foster the growth of those plays so they can be produced as major play productions. The development of new play productions was a major component of his tenure at the Trinity Repertory Company. Sixteen world premiere productions were produced there, under his leadership. He directed four of those productions: Anthony Clarvoe's Ambition Facing West; Tony Kushner's Homebody/Kabul; Paula Vogel's The Long Christmas Ride Home; and Rinne Groff's The Ruby Sunrise.

This thesis is a study of the dramaturgical development of those four world premiere productions he directed at Trinity. Draft scripts and performance scripts for these plays were consulted to note significant textual improvements in the development of each play. The findings, within each play examined for this thesis, show Mr. Eustis' talents for the selection of potential new plays as well as the ability to guide playwrights in improving such plays for performance. This thesis also notes the overall opinions of critics on each production. Not all of these productions were critically well-received, but they demonstrated the risk Mr. Eustis took in presenting new work to audiences of Trinity.
\end{abstract}




\section{Table of Contents}

Introduction................................................

Ambition Facing West.............................................................5

Homebody/Kabul.......................................12

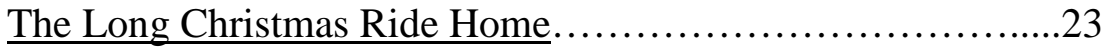

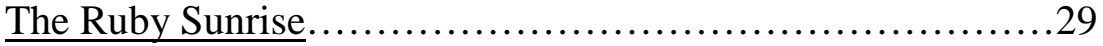

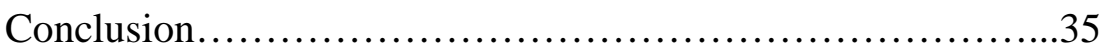

Works Cited

Appendix:

World Premieres at Trinity Repertory Company

During the Tenure of Oskar Eustis 


\section{Introduction}

Oskar Eustis came to Providence, Rhode Island's Trinity Repertory Company in 1994 to head the company as its artistic director. Its longtime founding artistic director, Adrian Hall, had moved on to other theatre ventures in 1989, and the theatre faced a long transitional period of reestablishing itself as a powerful American regional theatre with a significant influence on its local community. The theatre experienced new artistic directing leadership under Anne Bogart and then Richard Jenkins for the subsequent five years after Mr. Hall's retirement. It still was in great need, though, of an influential artistic director who could successfully propel the company in a distinct and successful direction for its local audiences as well as position itself once again as a leading and innovative force in American regional theatre. Mr. Eustis was most likely selected by the Trinity Rep's Board of Directors as the theatre's fourth artistic director in 1994 because he had a strong reputation of collaborating with playwrights and assisting them in the development of their new work for successful new play productions.

Like many other professionals in the theatre business, Mr. Eustis began his career as an unsuccessful actor in New York City, before discovering that he was best suited to other areas within the theatre business. He moved to San Francisco from New York City in 1978 and took part in a radical and edgy fringe theatre called the Red Wing Theatre. During this time, he discovered his niche was not so much in performing as it was in developing new plays. He used that niche to his advantage by taking the resident director and dramaturge position at San Francisco's more mainstream theatre, the Eureka Theatre Company, in 1981. He served in that position until 1986, when he was promoted to the 
theatre's artistic director position. He worked as the artistic director of the Eureka until 1989, when he moved to Los Angeles to become associate artistic director of the prestigious Mark Taper Forum theatre.

During his tenure at the Eureka Theatre, he discovered such up-and-coming playwrights as Emily Mann and Tony Kushner. He worked with Ms. Mann on the development of her play, Execution of Justice, which went on to great critical success. He also commissioned Tony Kushner to create what would eventually become the twopart play saga, Angels in America. Mr. Eustis attended a workshop production of Mr. Kushner's A Bright Room Called Day and was mesmerized by the play and its production. Soon after Mr. Eustis saw that production, he began working professionally with Mr. Kushner and commissioned Mr. Kushner to write Mr. Kushner's famous Angels in America play series. Although the first play of the Angels in America series did not have its world premiere until 1991 at the Eureka Theatre, after Mr. Eustis had left, it was Mr. Eustis who initially collaborated with Mr. Kushner on the development of the Angels in America series. The series eventually went on to have critically successful productions at the Eureka Theatre, the Mark Taper Forum, and Trinity Repertory Company. The first play in that series, Angels in America: Millennium Approaches, was honored with the 1993 Pulitzer Prize in Drama for Mr. Kushner as well as numerous other theatre accolades.

A big part of the Trinity Repertoire, during each season of Mr. Eustis' ten-year tenure, was the presentation of world premiere productions at the theatre. There were sixteen world premiere productions at Trinity Rep during his leadership (refer to attached 
Appendix for listing of world premiere productions). He himself directed four of those premiere productions at Trinity Rep: Ambition Facing West, by Anthony Clarvoe; Homebody/Kabul, by Tony Kushner; The Long Christmas Ride Home, by Paula Vogel; and The Ruby Sunrise by Rinne Groff. While some of these premiere productions may not have been extremely polished plays and/or critically well-received plays during their stints at Trinity Rep, the majority of them were significantly better in their performance texts than they were in their early drafts, and most experienced at least modest success with other theatre runs.

The immediate goal of any playwright is to get his or her work produced as much as possible, and the world premiere plays Mr. Eustis directed all have succeeded in doing that. One of Mr. Eustis' greatest attributes as a director and dramaturge is that he has the ability to note the greatness within a draft of a play. He can then go on to work with the playwright on eliminating the weaknesses of that draft and transform the play into a good production, no matter how rough and undeveloped that initial draft may be. It may not go on to become a great production, but it is bound to be a much more intricate and coherent play in production than it is in its early drafts. Such was the case with his productions

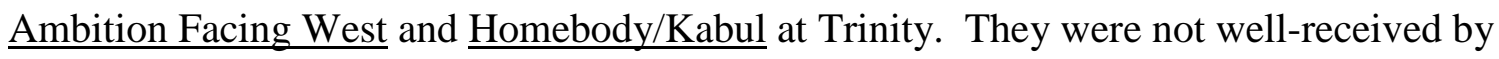
the critics, but their performance texts were far superior to their early drafts. In contrast to the development of those first two world premiere productions Mr. Eustis directed at Trinity, his productions of The Long Christmas Ride Home and The Ruby Sunrise did not have much revision from their early Trinity Rep drafts to their performance texts. The lack of revision needs for those productions proved that Mr. Eustis' abilities in 
selecting well-written plays for production improved greatly as he continued as artistic director of the Trinity Repertory Company. Although he may have been able to select better plays for production as he got older, his abilities to assist in the development of new plays are exceptional. While some of the world premiere productions he directed at Trinity could have been improved even more so than they were, the decisions to produce them were never completely regrettable. 


\section{$\underline{\text { Ambition Facing West }}$}

Mr. Eustis' first venture directing a world premiere production at Trinity Rep was on Anthony Clarvoe's Ambition Facing West. The play was part of a new event Mr. Eustis initiated at Trinity Rep, entitled the Providence New Play Festival. During that festival in the spring of 1997, Ambition Facing West was being presented with another new play, Paula Vogel's The Mineola Twins, in separate productions. The play, even in its production at Trinity Rep, lacked continuity as well as a plausible and sufficient plot. It did mark an accomplishment for Mr. Eustis, though, in that he assisted Mr. Clarvoe in the play's development from its early stages as a series of random scenes barely relating to each other to a play that had somewhat more continuity and a slightly more coherent plot.

The plot of the play begins in Croatia just before World War I, with a young and ambitious adolescent, Stipan. Stipan aspires to expand his small world beyond his remote village in Croatia. He begins this exploration of a world beyond his own by learning to read Latin with the local priest, Father Luka, even though learning to read was forbidden by his father, who ironically is never seen or heard from in the play. It is stated in the play that Stipan experiences brutal beatings, from his father, for learning to read. In the meantime, Stipan meets Ivo, an older Croatian who moved to the United States when he was an older adolescent and is now is a retired man who has had a successful working life exploring other parts of the world as well as establishing residence within the United States. Ivo has come to visit Croatia and he becomes a mentor to Stipan. Stipan looks up to Ivo since he is the epitome of what he hopes to become when he grows 
up. This initiates Stipan's ambition to go west to the United States to find a better life. These ambitions to go west and find a better life is the driving force of the play, hence the title, Ambition Facing West.

Eventually, Stipan settles in Wyoming and gets married to an Italian woman named Josephina. This second part of the play takes place in the 1940s when World War II is at its peak when American distaste for Italians, Japanese, and any other nationalities, from countries of the anti-American Axis Forces of that period. It is not known what has occurred in Stipan's life between his departure from Croatia and this point in his older years in the United States because such information is not discussed or dramatized in the play. Stipan lives a better life in the United States, but he still struggles to earn money in difficult mining jobs and encounters discrimination directed at him. He and his wife have one teenage daughter, Alma, who is confused about her identity due to the fact that her classmates question the American patriotic devotion of her parents. These classmates see her parents as something other than traditional Midwestern Americans and they scrutinize her because they do not know many people outside of that American prototype. Alma also has a boyfriend, Jim, who also has immigrant Italian parents. Alma does not really know what to think of her parents' heritage, but Jim is ashamed of his parents' Italian heritage. Jim joins the Air Force to declare his American patriotism in protest of his parents' heritage. The Air Force eventually sends him off fighting in the Pacific and he gets killed. Alma is devastated over the loss of Jim, but her parents encourage her to move on and go to college. 
The third part of the play consists of an older, middle-aged, and more cynical Alma meeting her son, Joey, in Japan. She sent him there to go to college, and he becomes fascinated with the place. Older Alma is now a successful business woman and has been offered a promotion by her company to run its branch in Croatia. She wants to bring Joey to work alongside her in Croatia, but Joey has become fascinated with Japan and its Buddhist Religion. He therefore refuses to join Alma in Croatia. In essence, Joey becomes the only character that is at ease and comfortable with his move west of his natural origins in America.

In the original draft of the play, Jim is simply a friend that accompanies Young Alma on a trip to do a school reporting story on a local pilot. Young Alma also moves on to go to Stanford University in California and meets her husband, Ted. Trouble arises in the marriage because Alma does not think Ted understands her origins; she believes that his Anglo-Saxon background has left him safe from experiencing discrimination. Ted also is more carefree than Alma and that becomes a problem for her as she is a highly cautious person. Neither of these characters helped explore the idea of a greater life in the West and really did not serve much of a purpose in the context of the play. Therefore, the character of Ted was eliminated in the final performance script. As mentioned above, Jim's role in the play becomes more significant and meaningful in the performance script, since he is a source of great loss for Alma as he loses his life serving in the Air Force.

The original script seemed to consist of too elaborate scenes that prevented any continuity and correlation between the three main subplots of the play. These original draft scenes went into unnecessary details on the conflict dramatized in each scene (i.e. 
Young Stipan's fight with his mother to leave Croatia; Young Alma's fight with her parents to learn about their origins; Older Alma's fight with her son Joey to go with her to Croatia). Many of these scenes were redundant in their focus on these conflicts and lacked the ability to propel the plot forward and/or expand upon the plot. These long scenes also made it difficult to connect the three subplots, which put forth a lack in connection to the overall theme of the appearance of a better life when one moves west. It was not unusual to question the feasibility of presenting such material in a successful performance because the scenes were too extensive and discontinuous to be presented as a successful play.

These aspects of the play were greatly improved in the performance script of the play. The scenes were much shorter and concise, which greatly improved the pace and continuity of the plot. There was also a change in scene direction in that it grouped scenes with similar themes, moving back and forth between the experiences of the characters in the three main subplots. For instance, the opening scenes of the play include a scene in which Young Alma is told to turn off an episode of 'Bulldog Drummond' on the radio, by her mother, and Alma then questions her mother about the cultural origins of her mother and Stipan. After this, a scene where Older Alma is fretting over her son Joey's obsessions with his walkman and his curiosity to know about what has happened to his long-lost father. These two scenes are obviously quite similar in their actions and therefore show the similarities in character between Young Alma and Joey. Such juxtaposition brought about more succinct continuity of the plot and themes within this play, making this play better-suited for production. 
Unfortunately, the majority of critics' responses to the production suggested that the play still needed some work to make the writing more palpable. Many critics thought that attempting to integrate three distinct subplots together into the context of one play was a little too much. In the review of the production in the Providence Journal, reviewer William T. Gale further comments on playwright Anthony Clarvoe's writing: “As his play flashes from generation to generation, from Eastern Europe to Japan, from parents to children, it creates a huge world, one that's difficult to handle" (Gale, Para. 3). Due to the fact that this play covers so much territory, many reviewers wondered if the play still needed work since the three subplots still had not greatly elaborated on the main theme of the play in one finding a better life further west and the realities that come about with that dream. In Variety, reviewer Markland Taylor noted that the ideas of Mr. Clarvoe were not “...fleshed out with sufficient dramatic skill, remaining ideas rather than becoming a play" (Taylor, Para. 6). Even throughout the performance script of the play, it was difficult to know whether the overall theme of the play was that there is a better life to be had when one moves West, life is best when you are situated in your location of origin, or that one's initial homeland brings about the most tranquility and happiness in life. Joey stays put in Japan and seems to be the only person who is at peace with his new surroundings. Such an ending suggests that one can only be happy where they can be stable and at peace with themselves. Knowing that Alma goes back to her Dad's origins in Croatia, though, suggests that one can only be happy by remaining in their familiar place of origin. These themes conflicted with each other and really 
questioned whether or not the main theme of this play was determined before this production.

Another major problem critics had with the play was that the characterizations of Young Alma and older Alma were vastly different. Young Alma is a sensitive and optimistic girl. Older Alma is a cynical, sarcastic, and miserable woman. They are two starkly different attitudes and bring about the possibility that Young Alma and Older Alma were two vastly different characters. While the loss of Jim may have brought about sadness and despair in Alma, it surely cannot be the sole reason for such a miserable outlook on life in her older years. Also there is not much information about what happened with her first husband in the performance script. Such information could have brought about a better understanding of the stark transformation in Alma's character. Reviewer Ed Siegel makes a good point on the stark character transformation in his Boston Globe review of the play, noting "we are asked to take this central notion of the play as a matter of faith, that overassimilation has a ruinous effect on the soul" (Siegel, “Trinity's 'West' Fulfills Most of Its Ambitions”, Para. 9). That is an interesting point, but it does not seem to be a sufficient reason for the stark contrast in Alma's character. The play really needed additional explanation of Alma's character transformation to make it justifiable.

Having three major and distinctly different subplots only brought about confusion in what the overall theme of the play was. The play may have been more focused and well-received had it been condensed to focusing on the life of one major character and the realities that character faced with his or her ambition to go west. The trouble with 
playwriting and writing multiple distinct plots in one play is that it is difficult to bring them together into a continuous and believable plot. Ambition Facing West suffered from this problem of overreaching. Its first draft problems brought about the question of whether or not this play could be successfully produced, since there really was no connection between the three subplots. The immense improvements in continuity, succinctness, and conciseness in the performance script are not only a credit on the writing abilities of Mr. Clarvoe, but also a credit to the dramaturgical guidance of director, Oskar Eustis. It really is a great achievement and credit to Mr. Eustis that he was able to work with Mr. Clarvoe to develop what was initially a poorly coordinated series of random scenes and transform them into a decent and palpable play. 


\section{Homebody/Kabul}

Since Mr. Eustis had worked with playwright, Tony Kushner, previously on the development of the Angels in America play series, it was not unexpected for the two to collaborate on another production. Mr. Kushner visited Afghanistan during the late 1990s and was able to take note of the stark differences between Afghani and American cultures. He was there at a time when the militant group, the Taliban, was the predominant governmental power in the country. The core beliefs of the Taliban rested on radical religious beliefs contrary to those of traditional Muslim religion, condemning Muslims who were sympathetic to Americans and American-loving Westerners. During the late 1990s, the Taliban harbored and protected the anti-American terrorist group, $\mathrm{Al}$ Qaida. Al Qaida is well-known for its terrorist attacks against Americans and Americanloving Westerner. The terrorist group put together training camps in Afghanistan under the guidance of the Taliban. Al Qaida's most infamous terrorist attack was its bombings of the World Trade Center in Manhattan as well as the Pentagon in Wsahington D.C. on September 11, 2001. Once the government of the United States confirmed Al Qaida's responsibility for those attacks, the United States demanded that the Taliban government give up the $\mathrm{Al}$ Qaida leader, Osama Bin Laden, and shut down the $\mathrm{Al}$ Qaida terrorist camps in Afghanistan. Naturally, the Taliban refused to comply with the United States and that prompted the United States to go to war against the Taliban. The government power of the Taliban was eliminated by the middle of 2002, but the great loss from September 11 was still felt by Americans and other residents of the United States. 
Mr. Kushner took note of that anti-American/anti-Western sentiment on his visit to Afghanistan, in the late 1990s, and in turn decided to write Homebody/Kabul. He wrote the play prior to the World Trade Center attacks. Since a great part of this play gave so much information on the Taliban culture that existed in late 1990s Afghanistan, it was inevitable that it be produced after the September 11 attacks. Not many Americans truly were aware of this radical Muslim militant culture of the Taliban-controlled Afghanistan immediately after September 11, 2001. This was a time when American fears of subsequent Taliban and anti-American terrorist attacks were arguably at their peak. Mr. Eustis and Mr. Kushner therefore saw an opportunity to educate audiences on the role of the Taliban in Afghanistan, prior to the September 11 attacks, by presenting the fictionalized drama of Homebody/Kabul.

The play did have informal readings in various performance venues prior to the September 11 attacks, but it really had a significant purpose to be performed in the aftermath of those attacks, since its themes focused on the instability and anti-Western sentiment of a Taliban-influenced Afghanistan in the 1990s. Mr. Eustis and Mr. Kushner had such a great professional working relationship on other play production collaborations so it was a given that Mr. Eustis would have some involvement in the first American productions of the play following September 11. The play's first official New York performance premiered on December 19, 2001, at the New York Theatre Workshop. It was quite eerie and ironic that a play would explore the nature and culture a country that harbored one of the most dangerous terrorist groups ever since the play was highly resonant of the political climate in the world when it was first presented in New York. 
Mr. Kushner's comments on the irony in writing a play that is so in tune with current events in his afterword within the play's revised text: "If you choose to write about current events there's a good chance you will find events you've written about to be...well, current" (Kushner 144). Mr. Kushner also made mention of the fact that, although it was impossible to predict the tragedy of September 11, “...the information required to foresee, long before $9 / 11$, at least the broad outline of serious trouble ahead was so abundant and easy of access that even a playwright could avail himself of it" (Kushner, "An Afterword" 144). It was quite amazing that Mr. Kushner was able to take note of this terrorist culture in Afghanistan and write a play about it prior to the explosive aftermath of September 11, when almost the entire world became aware of this Taliban government and its harboring of the Al Qaida.

Mr. Eustis worked on the dramaturgy of the play alongside Mandy Mishell Hackett for the New York Theatre Workshop production in December of 2001 (which was directed by Declan Donnellan). The production was poorly received by critics mainly due to the fact that it was a lengthy production that lasted about three hours and forty minutes. When Mr. Eustis directed the play at the Trinity Repertory Company in March of 2002, he and Ms. Hackett managed to work with Mr. Kushner in shortening the play to about three hours and twenty minutes. Luckily, it was slightly better received by critics in Rhode Island than it was in New York.

The play begins with a long monologue by a British middle-aged woman, the Homebody. The Homebody has become fascinated with the Afghani culture depicted in her old guidebook to Afghanistan. She speaks directly to the audience and expresses the 
myriad of feelings she has while speaking. She lives a sheltered existence as a housewife and her only access for her to explore the world outside of herself is through her personal book collection. Her knowledge of Afghanistan is limited to what is mentioned in her dated guidebook on the country. She takes note of the fact that Afghanistan has been a depressed country and one that unfortunately has been a target for bad luck through its many transformations. She even mentions the rumor that the biblical villain, Cain (killer of his brother Abel out of jealousy), was buried in Kabul. This emphasis on the bad luck of Afghanistan is interesting because it somehow relates to her lack of excitement and exploration in her own life. Even though her guidebook depicts Afghanistan as a dangerous place with a target for bad luck, it is her idea of a wonderful world because its historical tragic background appears to relate to her mundane and sheltered existence.

“...The Homebody’s monologue takes place at a bright intersection of public sweep and private reflection, of galloping history and individual destiny" (Brantley, "One Woman's Quest...”, Para. 10). The woman intersperses discussions on her feelings about her lonely life, her family, and politics throughout her ramblings on the history of Afghanistan as seen through her guidebook. She and her husband have been diagnosed with depression and are taking separate medications to treat their depression. Being so lonely and disenchanted with her life in London, she amuses herself by taking her husband's pills just to feel what he is feeling and to understand why he is the way he is. She also notes that her daughter is a confused and incomprehendable individual in her twenties. So there is a major lack of intimate family connection that leaves a major void in her life. She also had become fascinated with an Afghani salesman at the Afghani 
culture shop where she buys hats for a party. While at a local London Afghani shop, the woman discovers that its Afghani salesperson has a smooth-cut angle of finger tips missing. She suspects that this loss of finger tips is from his participation in the Afghani war with Russia in the 1980s. She mentions that she asked him about the injury and she claims this was his answer to her: "I was with the Mujahideen, and the Russians did this. I was with the Mujahideen, and an enemy faction of the Russians did this. I was with the Russians, I did informer's work for Babrak Karmal...” (Kushner, Homebody/Kabul I.1.23). Such an answer only leads the audience to wonder if most of these interactions and live events are fabricated and/or just a fantasy. The only truth this woman seems to reveal about herself is that she is lonely and depressed as she cannot understand her husband or daughter. This unfortunate truth within the mundane world of the woman's life is the probable reason why the woman randomly takes off for Kabul, Afghanistan, and is never seen again.

After the Homebody's long monologue about her life and the history of Afghanistan, she is never seen again in the play as her husband and daughter, Milton and Priscilla Ceiling, later discover she is missing. Milton and Priscilla go on a journey through Kabul to search for the missing woman and experience many setbacks, both cultural and personal, throughout their journey. Milton's only venture to anywhere other than his hotel room in Kabul is a trip to a hospital. On that trip, he is accompanied by a Taliban Minister, Mullah Aftar Ali Durranni, and he meets a hospital doctor, Doctor Qari Shah, who tells him that his wife's body parts were received by the hospital and that she is dead. Milton believes that these people are being honest with him; however, Priscilla 
is rebellious and her stance is that there is a real possibility this information may be false. Milton becomes so depressed and distraught by the news that he avoids the outside world and stays in his hotel room the majority of the trip. He becomes quite good friends with a young British aid worker, Quango Twistleton. While Quango hates Afghanistan, he remains there because he can easily feed his drug habit with cheap opium in Kabul. Milton and Quango eventually succumb to being drinking/drug-sharing buddies.

In the meantime, Priscilla goes off on a search to really find out what happened to her mother. This venture is challenging for Priscilla because she has to wear a Burka at all times and loses power, because she is a woman and women are considered secondary human beings in this world. She is even terrorized by a Taliban soldier for simply lifting up her Burka (exposing her face) to pick up her Discman. While being terrorized by this Taliban soldier, she is saved by an escort, Khwaja Aziz Mondanabosh, who helps her get around Kabul to help her conduct this search for her mother. He apparently has a love of poetry and he asks that she take some of the poems he has written and mail them to a friend of his in London. Khwaja leads Priscilla to a mysterious hat dealer, Zai Garshi, who tells her that her mother is not dead, but is happily married to a new Afghani husband. Zai tells her that her mother wants to erase her past and therefore does not want any contact with Milton or Priscilla. He promises to communicate with Priscilla's mother if Priscilla promises to assist her mother's new husband's former wife, Mahala, in escaping to London. Mahala is a former librarian who is independent and well-educated, but she simply cannot comply with being a secondary human being and is therefore a nuisance to her former husband. 
Although Priscilla and the audience are left to believe that this story given to her by Zai is true, there is a distinct possibility it is a fabrication to get Mahala out of the country. Milton and Priscilla never find the Homebody, and it is unknown what actually happened to the woman. Instead of going home with the Homebody as they hoped, they end up escorting Mahala out of the country. While they are all getting ready to go home to London at the Kabul airport, they are confronted by another Taliban guard and Mullah Aftar Ali Durranni at the airport. The guards attempt to get Khwaja's poems from Priscilla through threat of physical assault. In actuality, the poems were a special code to be sent to the Israeli Intelligence Group, Massoud, and Mahala is the wife of Doctor Qari Shah. It is unlikely the Homebody married Mahala's former husband and that this tale is simply an attempt for Khwaja and Zai to get Mahala out of the country while exchanging intelligence information with British and Israeli intelligence based in London. Luckily, Milton, Priscilla, and Mahala manage to get out of the country to avoid additional Taliban confrontation. Mahala eventually goes on to live with Milton and pursue a romantic relationship with him, and it is suspected that Khwaja's information is sent to the appropriate intelligence agencies. The whereabouts of the Homebody, whether dead or alive, remain unknown.

The original draft of the play was extremely long and overreaching. One of its major problems was that the scenes had too much dialogue and did not get to the point fast enough. One of Mr. Kushner's strengths within his playwriting is that he is an expert in constructing beautifully crafted speeches and dialogue, like this response by Khwaja to Priscilla when asked about the meaning of the poem he read out loud to her: 
KHWAJA It is very simple. It is about someone waiting in a garden, in the snow. Deep within, someone waits for us in the garden. She is an angel, perhaps she is Allah. She is our soul. Or she is our death. Her voice is ravishing; and it is fatal to us. We may seek her, or spend out life in flight from her (Kushner, Homebody/Kabul III.1.118).

This speech is beautifully crafted in that it is symbolic of Priscilla's quest to find her mother. While Mr. Kushner has many beautifully constructed speeches like this in his play, he also has a lot of dialogue consisting of extensive vocabulary that really is not used in everyday English language. The first draft had many jumblings of such vocabulary like the Homebody's reference to the hats at the Afghani culture shop as “...abbreviated fezlike pillboxy attenuated yarmukite millinarisms...” (Kushner,

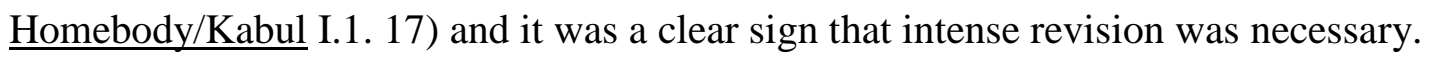
Also, there were many scenes and speeches that just seemed out of place and unnecessary since they did not advance the plot. There was one scene where a Lady in a Burka agonizes over the distress of a child with a disease. It was quite interesting in that it showed the kind of agony mothers face in Afghanistan, but it really had nothing to do with the plot of the play. Then there is a scene where Priscilla meets a permanent fixture of Cain's grave, the Marrabout. In this scene, she lets out her feelings about the challenge of finding her mother and her inability to maintain a normal romantic relationship. The scene provided insight into the character of Priscilla; however the Homebody is the focus of the play. It really was not important to get insight into the character of Priscilla when the Homebody is what drives the plot of the play.

Fortunately, redundant and unnecessary scenes were eliminated in the revised version of the play for Trinity Rep. Also there was less elaborate vocabulary in the 
revised version of the play. While the long phrase for the Afghani hats remained in the Homebody's speech, much of the dense vocabulary was minimized or eliminated in the revised version for Trinity Rep. The significant beautiful dialogue and speeches remained in the revised version and were able to have greater significance since much of the unnecessary dialogue and speeches were eliminated.

Unfortunately, the New York Theatre Workshop production was horrifically received by critics. As exemplified by such over-elaborated dialogue like the Homebody's hat phrasing, many critics felt the play was too lengthy and long-winded to be produced in the first place. There was still a feeling that there was too much overuse of unnecessary dialogue and vocabulary to make the play sound beautiful. John Simon, of New York Magazine, especially did not appreciate the density of the dialogue and stated this about Mr. Kushner's writing within the play: "Logic, in his hands, becomes logorrhea; illumination is bypassed for obfuscation; character is merely an excuse" (Simon 60). While this may have been an exaggerated statement brought on by the critic's obvious dislike of the production, the play was still too dense to be successfully produced. It did have great potential to be a good production and Ben Brantley, of the New York Times, made mention of the play's potential and noted "the high points of this lumbering yet compelling evening testify that Mr. Kushner can still deliver his sterling brand of goods: a fusion of politics, poetry and boundless empathy transformed through language into passionate, juicy theater” (Brantley, “One Woman's Quest...”, Para. 8).

Although the reviews of the New York production were quite negative, Mr. Eustis must have taken note of the potential the play had when he decided to stage it at Trinity. 
Many directors might have turned away from an undertaking of a second production of a play that was so horrifically reviewed, but it was clear to Mr. Eustis that this play would improve through revision as well as a presentation in a less demanding and cutthroat market for theatre. The risk was worthwhile as the Trinity Rep production seemed to work out better in terms of critical receptance. Channing Gray, of the Providence Journal, saw the Trinity Rep production and noted, "Homebody/Kabul is unorthodox, to be sure, but not as unwieldy as reviews of the New York productions indicated" (Gray, "Trinity Rep's Homebody dazzles.”, Para. 17). Carolyn Clay, of the Providence Phoenix, praised the play as well, noting, “...Kushner's first major work since Angels in America is as splendid as it is disjointed, a grand Cuisinarting of history, politics, family disconnection, and vocabular audacity" (Clay, "Prophet and loss...", Para. 2).

One of the major critical complaints of both the New York and Providence productions was that it was not clear why Milton and Priscilla were in such need of finding the Homebody in the first place. It is obvious in Homebody's monologue that she does not hold them in high regard. The reasoning behind them going to Kabul is therefore unclear, because their characters were not fully developed. Carolyn Clay notes that the play's major flaw is that "...the most fully human, original, and interesting character, the Homebody, disappears a third of the way through" (Clay, "Prophet and loss...", Para. 10). Ben Brantley took note of that as well when he stated, "Mr. Kushner has yet to crawl into the minds of his other characters as intimately as he has with the Homebody” (Brantley, “One Woman's Quest...”, Para. 13). The pain within the unhappiness the Homebody has within her mundane life is greatly noted in her long 
monologue and it is the reason why audiences of the play can sympathize with her character. It is not clear whether or not Milton and Priscilla love the Homebody enough to be looking for her in Kabul. It is also quite difficult to have empathy for either character. For two characters that are supposed to be the protagonists of the play's second act, there is not much within the characterizations that suggest they should be in the role of the play's protagonists.

Although Homebody/Kabul may not have acquired the same success that Mr. Kushner had with the Angels in America play series, the first two major productions of the play were not complete failures. They seemed to have been stepping stones to more refinement in additional productions of the play. Following the New York and Providence productions, the play went on to have additional productions at other prominent theatres, such as London's Young Vic, Chicago's Steppenwolf Theatre, and the Mark Taper Forum of Los Angeles. Had Mr. Eustis not seen the potential the play possessed even through its overt weaknesses in the initial New York production, the play probably would not have gone on to be produced in other venues besides the New York Theatre Workshop. The play's subsequent productions are proof that a dormant play can be made great with the help of someone willing to take risks and use their dramaturgical skills to work on the development of the play. Oskar Eustis was definitely that person when it came to the development of Homebody/Kabul at Trinity. 


\section{The Long Christmas Ride Home}

Mr. Eustis' third venture directing a world premiere at the Trinity Repertory Company came in 2003, when he was given the opportunity to direct Paula Vogel's The Long Christmas Ride Home. Ms. Vogel had had two other successful productions at Trinity Rep in The Mineola Twins and her Pulitzer Prize winning play, $\underline{\text { How I Learned to }}$ Drive. She also had taken on the role of Professor of Playwriting at the Brown University/Trinity Repertory Company Consortium, and so it was not surprising that Mr. Eustis decided to direct her The Long Christmas Ride Home. The play is about a family's troubles on Christmas and the disillusionment the fantasy of Christmas brings to this dysfunctional family. While the theme of the disappointment with Christmas has been explored in many plays, the uniqueness of the play lied in the unusual theatrical elements it incorporated. Some of these successful elements included: life-like puppets (portraying the roles of innocent children), which were created for the Trinity Rep production by puppeteer, Basil Twist; and the influence of slow-moving, yet tightlychoreographed Japanese Noh theatre traditions.

The play was influenced primarily by the works of playwright, Thornton Wilder, especially by his play entitled, The Long Christmas Dinner. Several of Wilder's works, most notably Our Town, were influenced by the Japanese Noh theatre traditions in that they had a narrator describing the events occurring on stage, while the events were slowly performed, yet carefully choreographed. Our Town is well-known for its stage manager character describing everything that is going on within the play. That same formula, used frequently by Thornton Wilder, is used in The Long Christmas Ride Home. A man and a 
woman narrate the events that occur on a family's ride to visit their grandparents on Christmas. Surprisingly, the man and woman narrators are the parents in the front of the car. Their three children, Rebecca (age 12), Stephen (age 10), and Claire (age 7) are portrayed by puppets who literally act like out-of-control children. They bicker over little things and annoy their parents, creating a stir of craziness on the way to their grandparents' house. The narrators discuss the different feelings each character experiences while they are in the car. The father is dreaming about his mistress, another mother who is more attractive to him than his wife. The wife dreams about having a man hold and console her as she tries to put away thoughts about her husband's philandering. Stephen wonders why his father does not love him. He also wonders whether or not his attraction to boys at school is normal. Rebecca fantasizes about her school crush. Claire dreams of the beautiful meal and presents she will receive when the family arrives at their grandparents' house.

When the family gets to the grandparents' house, they are faced with a disaster. Both grandparents are played by one man. They literally give everyone in the family junk from their attic as Christmas presents. As they all sit down to eat, the grandfather argues with the father over the father's inability to provide for his family, since the family lives in a rented apartment. This leads the father to become angry and toss over the dinner table, thus ruining Christmas dinner. The father then makes his wife and children leave the house and storm back into the car. This anger eventually leads to the family car dangerously sliding on ice into a horrific car crash. 
It is not known what exactly happened to the family after the car crash, but the play propels in time to about twenty years later. It reflects on what has become of the lives of each of the children. Strangely, this second half of the play does not have a formal narrator like the first half of the play. Rebecca has become an instable philandering woman like her father, but she also has to deal with the fact that she is pregnant and she is not sure who the father is. The audience sees her at a point when she is trying to get into the house of her boyfriend (played by a puppet). Her boyfriend refuses to let Rebecca in, and she is relegated to arguing with him outside his house in dreadfully cold weather conditions. Claire has lost her girlfriend to a rival woman and is forced to stand outside her former girlfriend's house while pleading for her and reflecting on earlier times when she was able to land any beautiful woman she desired. Stephen is feeling sorry for himself because he is aging (he is no longer a young stud and now has to tweeze the gray hairs out of his head every morning). He also has been recently dumped by his partner so he goes about making himself feel better by getting together with some random guy (an adult-sized puppet) in the bathroom of a bar. Sadly, this encounter leads Stephen to become inflicted with AIDS, and he loses his life to the virus.

Unlike the other two world premiere projects Mr. Eustis directed at Trinity Rep, this play did not really undergo much revision between its sixth draft and its performance script. Its first through fifth drafts may have been revised greatly by Ms. Vogel prior to the sixth draft, submitted to Trinity. While it did not need as much of an overhaul as

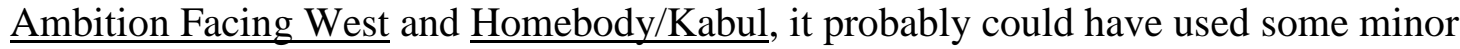
enhancements. Having the man and woman narrators portray the characters of the Man 
and Woman in the car was slightly confusing, and there could have been four actors instead of two portraying those roles. This comment also applies to the role of the grandparents, which was intended to be played by one person and probably should have been portrayed by two people. One person playing the role of Grandfather and Grandmother at the same time is quite confusing. It is quite difficult to distinguish the difference between the two roles even if the actor is greatly talented and can easily make the transition from one role to the other in a split-second. There are very few actors who can successfully make such transitions. Such difficulty in comprehending the role an actor is playing at a given time is unnecessary. It was also quite shocking that the second part of the play did not continue the same formal narration style as the first part of the play. Some of the dialogue by the characters, in the second act, was quite formal and may have been better suited to a separate narrator. For instance, the scene where Stephen realizes he made a mistake by randomly getting together with some man at a bar is a little too formal and poetically constructed to be stated by the Ghost of Stephen:

\section{GHOST of STEPHEN}

-Oh! How my sisters will cry. I could feel the virus entering my body. But I could not undo what had been done. And for next several years, I could feel the virus multiply with a ferocious beauty-replicating patterns that changed and mutated (Vogel, The Long Christmas Ride Home 50).

Such dialogue is probably best-suited for a narrator since it is the narrator who is usually the most formal speaker. The characterization of older Claire is challenging too because it does not possess individuality and uniqueness from the characters of Rebecca and Stephen. Claire is a philandering womanizer who has realized that her life is empty, because her long relationship with her girlfriend has ended with the girlfriend's decision 
to get together with another woman. Rebecca is a man-hungry philandering woman who has realized her life is empty now that she is pregnant and has no idea who the father is. There really is nothing, other than the fact that Claire is a lesbian, which sets her apart in character from Rebecca. That issue could have been addressed in the final revision as well.

The production was well-received by critics, even with its textual flaws in the second act, because it took a risk in experimenting with so many unconventional theatre elements and was so successful in its incorporation of Noh theatre elements as well as life-like Bunraku puppetry. Ben Brantley, of the New York Times, took note of the influence of these unconventional theatrical elements: “...in daring to interject the traditions of classic Japanese theater, including Bunraku puppetry, into a classically American tale, Ms. Vogel has found a norm that transcends and enriches her play's formulaic content” (Brantley, "Puppets Mine Unexpected...", Para. 4). Carolyn Clay, of the Providence Phoenix, took note of how genuine emotions were evoked on the faces of the puppet creations of Basil Twist, noting that they appeared like “...little masks of sorrow, elation, apprehension, and bewilderment" (Clay, "Fusion Feast...", Para. 1). Markland Taylor's comment, "with its adventurous blend of puppets, live actors and Japanese theatrical elements, it's Vogel's most daring work-and one of her best" (Taylor, Rev. of The Long Christmas Ride Home, Para. 1), sums up the feelings of most reviews of this production. Its plot may have been lacking in the second half of the play, but those weaknesses were outshadowed by the strengths of the puppets and incorporation of Noh theatre elements. 
While the play was not in need of great revision like Mr. Eustis' previous world premiere directing ventures, it was a great undertaking for any director to take on considering the demands of the unconventional theatre aspects within it. It must have been a great challenge for Mr. Eustis to figure out how these elements were going to be initially maneuvered and incorporated into the production. He may not have had a great role in the dramaturgical development of this play production, but he certainly had a lot to undertake in directing this difficult production with all its puppetry and Noh theatre elements. On its own, it could have been just another play about a family tragedy on Christmas, but its themes really had more meaning with the incorporation of the Noh theatre elements and Bunraku puppetry. The slow Noh-like pace of the play as well as the Bunraku puppets made pivotal moments of tension in the plot more poignant than they would be in more traditional forms of modern drama. 


\section{The Ruby Sunrise}

Mr. Eustis' final world premiere, at the Trinity Repertory Company, was The Ruby Sunrise, by up-and-coming playwright, Rinne Groff. Ms. Groff is a professor of playwriting at New York University. Prior to her debut of The Ruby Sunrise at Trinity Rep, Ms. Groff had experienced a modicum of success with her other plays on notable stages. Her earlier play, Orange Lemon Egg Canary, was presented at the Humana Festival of the Actors Theatre of Louisville, Kentucky in the spring of 2002. Two years later, Mr. Eustis directed the premiere of The Ruby Sunrise at the 2004 Humana Festival in Louisville. That production was actually a collaborative production between the Actors Theatre of Louisville and Trinity Rep. After its run in Louisville in March of 2004, it was brought over to Trinity Rep to be presented in Providence two months later. Although Ms. Groff had experienced some success in her playwriting ventures, she certainly was not as established as playwrights like Tony Kushner or Paula Vogel when Mr. Eustis directed world premieres of their plays at Trinity Rep. It was a gamble for Mr. Eustis to take on a play from a playwright who was not well-known; however, it proved to be one of the most successful world premiere plays during Mr. Eustis' tenure at Trinity Rep.

The Ruby Sunrise is a play about the despair brought upon its two heroines: Ruby and Lulu (Ruby's daughter). Young Ruby is ultimately determined to see that her goal of inventing the world's first television arrives at fruition and she comes quite close to achieving that goal; however her work is permanently thwarted when a bad electrical fuse blows up her lab and electrocutes her. Lulu, thirty years later, is determined to get her 
teleplay about Ruby's life aired on a major television network in New York. Lulu unfortunately discovers, however, that the television network cares more about presenting a feel-good teleplay that brings ratings rather than a show that depicts the real truth behind the story of Ruby. Ruby's dreams of inventing the first television as well as Lulu's dream of televising the actual tragedy of her mother's life are never realized and both characters are left in despair.

The first half of the play begins with young 16-year-old Ruby in 1920s Indiana. Ruby has run away from her abusive father to live with her "Aunt" Lois, who actually is the rejected old lover of her father and has no relation to the girl. She moves into her Aunt Lois' farmhouse against the wishes of her Aunt Lois and starts bringing about havoc to the place. Ruby has an insatiable curiosity for anything that has to do with electricity. She is seen as crazy by her Aunt Lois since she is a woman and working with electricity was viewed as a hobby for only men at that time. All of Ruby's projects are well-intended, but they bring about friction between her and Aunt Lois because Ruby will go to any lengths to explore her curiosity in the study of electricity. On a good note, she fixes her Aunt Lois' generator to actually bring electric light into the farmhouse; however, she then goes about stealing things (like the radio of her 21-year-old boarder, Henry) in order to try to create electrically transmitted light waves on a glass screen, showing pictures of other places, in the hopes of creating the world's first television.

Henry is in love with Ruby and he actually works to help Ruby realize her dream, hoping that she will eventually settle down with him. He goes so far to help her that he steals tools and electrical equipment from his agricultural college to assist her. His 
assistance to Ruby never turns out to be enough, though, since she always gets depressed when her experiments falter. Initially Henry sympathizes with Ruby, but her mood swings get to the point that he will do anything to destroy this project of hers. $\mathrm{He}$ attempts to get her to cease her work by bringing up an article he found in the local library, which discusses how scientists have already accomplished the feat of inventing the world's first television. Ruby still will not let go of her pride and argues that her invention is going to be larger and more significant the two-inch television these other scientists already invented. It is only when Ruby gets electrocuted and discovers she is pregnant with Henry's baby that she is forced to permanently let go of her dream and resign herself to living her life as an alcoholic in despair.

The second act of this play shows the events that occur with Ruby's daughter, Lulu, in 1950s Manhattan. Lulu is a smart and vivacious young woman in her twenties, who manages spontaneously to sneak into the offices of one of the most significant television networks and convince its most powerful producer, Martin Marcus, to hire her as his script girl. She then goes about proposing her mother's story to the network's head teleplay writer, Tad Rose. All goes well in the development of this teleplay with Tad in its beginning creative stages and this leads them become quite fond of each other and begin a romantic relationship. Trouble arises, though, when Lulu loses control over the creative development of the teleplay. Her first choice in actresses to play Ruby, Elizabeth Hunter, a genuinely talented stage and film actress, cannot be given the role of Ruby since she is blacklisted. Her replacement, Suzie Tyrone, is a very sweet stereotypical dumb blonde actress, who is chosen for the role by Martin because "she 
looks good wet" (Groff, The Ruby Sunrise, 39). That decision leads to another loss of creative influence, as the real situation of Ruby's getting electrocuted and the fire in her electrical lab is replaced by a scene in which the lab gets flooded, so that audiences can see Suzy wet. This loss of creative control over the project causes Lulu to become so hysterical that she is fired by Martin because of her angry outburst.

Eventually Tad persuades Martin to let go of the flood scene. He also manages to persuade him to let Lulu come back to work on the project. While there is compromise in Tad's allowing Lulu to get credit for writing the teleplay with him, Lulu must accept that Suzie will continue playing Ruby and that the truth of Ruby's story will never be completely told on television. The producer's whole point of placing the story on television is that it is a "feel-good" story to make audiences happy for an hour. There must be a happy ending so the decision is made for the teleplay to end with Ruby leaving her country home in Indiana, with best wishes from Lois and Henry, and setting forth on a journey of promise to work on her invention at RCA in Manhattan. Such an ending is a direct commentary on the manipulation of television programming. All a major producer like Martin Marcus cares about is winning audience ratings with a melodramatic onehour teleplay that has a happy ending. Ruby's real transition into a despair-ridden drunken mother, confined to her small world on a farm in Indiana, really had no place in bringing about ratings to Martin's network.

The Ruby Sunrise did undergo tiny revisions from its early draft in November of 2003 to its performance script for Trinity Rep. The initial story and themes did not really change from this earlier draft to its final performance script for Trinity Rep; these 
revisions consisted primarily of fixing grammatical errors. Ironically, it really was not necessary for the script to undergo drastic revision. The writing was pretty solid in the early draft. Unlike Mr. Eustis' other world premiere directing ventures at Trinity Rep, which either underwent great revision or were in great need of it, The Ruby Sunrise was really a completely producible play even in its pre-performance drafts. This is most likely why Mr. Eustis chose to take a chance on Rinne Groff's play, even though she was a relatively unknown playwright.

The play production at Trinity Rep was touted as one of the best productions Trinity Rep ever had during the tenure of Mr. Eustis. Critics praised the great script of Ms. Groff as well as the direction of the production by Mr. Eustis. Channing Gray, of the Providence Journal, noted, “Ruby Sunrise is not only clever, but endearing, with characters who we can't help but care about” (Gray, “A Finely Tuned Portrait...”, Para. 5). Ruby is the one of the central heroines of the play and it is quite difficult not to sympathize with her when she tells her Aunt Lois: “... all our differences could be settled around tables, instead of going to war. Television will be the end of war..." (Groff, The Ruby Sunrise, 30). While television certainly has not ended war, the prediction by Ruby is fascinating. It is sad to see Ruby falter in her path to glory. It is also upsetting to watch Lulu accept the fact that her mother's story will never be seen or told to a mass television audience.

The play's exploration of the manipulation of television programming was also praised in the reviews of the Trinity production. Frank Rizzo, of the Daily Variety, took special note of this aspect of the play when he praised its exploration of "...the art of 
storytelling as it pertains to the American love of reinvented lives" (Rizzo, Rev. of The Ruby Sunrise, Para. 1). In a world where television programming has been manipulated to suit the wants and needs of the viewer, it is quite difficult to tell what is real or not real even when a so-called biographical story is shown on television. Television producers have a tendency to tweak the truth for entertainment purposes. Such entertainment makes viewers become interested in watching television and their interest garners ratings. Not many viewers would want to watch the real story of Ruby's life so her story was greatly altered and falsified to make viewers happy.

The Ruby Sunrise was actually a culminating world premiere directing project that solidified Mr. Eustis' reputation in bringing new plays to Trinity Rep. He stepped down as artistic director of Trinity six months after the Trinity premiere of The Ruby $\underline{\text { Sunrise }}$ to take the position of artistic director at New York City's prestigious offBroadway theatre, the Public Theater. Since that theatre has always had a reputation of producing new and innovative plays on a regular basis, Mr. Eustis was really a good fit to succeed its outgoing artistic director, George Wolfe. He directed a production of The Ruby Sunrise at the Public Theatre in his debut season as artistic director. It was not as well-received by critics as the Trinity production; however, the fact that the relatively unknown Rinne Groff was able to have her play produced in an Off-Broadway production is quite astonishing. 


\section{Conclusion}

As Oskar Eustis progressed in his role as artistic director of the Trinity Repertory Company, his abilities to select quality new plays improved immensely. Initially, he seemed to have made rather poor decisions in selection of new play productions although he made up for such poor decisions by assisting in the improvement of the playwriting of such productions. With such play selections as The Long Christmas Ride Home and The Ruby Sunrise, Mr. Eustis showed that his ability to select new plays has improved since those plays required little to no textual improvement. It is obvious that he learned from his mistakes in selecting Ambition Facing West and Homebody/Kabul for play production and became more apt to select more complete new play drafts.

Ambition Facing West was not a complete disaster of a production, but it was a play that lacked continuity since its subplots lacked a succinct relationship to each other. Most directors probably would not bother reading through the entirety of the disjointed

first script of the play. Mr. Eustis obviously had a lot of patience in that he was willing to take on the endeavor of producing this play even with its many textual flaws. The patience paid off since the performance script of the play was a vast improvement to the weak first script. Even with the improvements, though, the play was still lacking continuity and coherence in its text.

When Mr. Eustis chose to work with Tony Kushner again, it was obvious he made that decision primarily because Mr. Kushner has a reputation for beautiful writing in such memorable plays as in the Angels in America play series. Although $\underline{\text { Homebody/Kabul }}$ was initially a lot longer than it should have been, it definitely had the potential to be a 
great play production. Mr. Eustis knew that he needed to work with Mr. Kushner in shortening the initial script to a shorter and speedier production. The overhaul of that first script paid off as the play garnered better critical reception in its production at Trinity.

The presentation of The Long Christmas Ride Home was a great risk for Mr. Eustis and Trinity, since the play required the use of extensive puppetry. It probably took a lot of patience and rehearsal to bring about the intense emotions evoked by the play's puppet characters. The play could have had textual improvement, especially in the second act, but those needs for such improvement were masked by the beauty of the play production's Bunraku puppets and Japanese Noh theatre elements. The incorporation of these elements was wonderful in the play's first act, but could not sustain its strength into the second act.

While Rinne Groff is not as well-known as playwrights like Paula Vogel and Tony Kushner, Mr. Eustis' decision to direct the world premiere of The Ruby Sunrise was an excellent decision. Most critics and audiences would probably argue that The

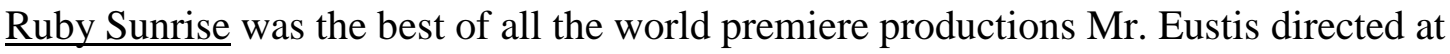
Trinity. Audiences could easily sympathize with the despair felt by Ruby in her failure to invent the world's first television as well as Lulu's failure to get television audiences to the actual truth behind the life of her mother. It was definitely well-received at Trinity because it was easy for audiences to identify with such likable characters as Ruby and Lulu. 
The risks Mr. Eustis took at Trinity Rep are indicative of his nature in directing and in choosing what kind of productions he is most interested in producing. It will not be surprising if he aggressively continues his devotion to the production of world premiere plays and new playwrights at the Public Theater, since there were sixteen world premiere productions, including the four productions he directed, during his tenure at Trinity. He has been primarily devoted to developing and presenting new plays since his early days at the Eureka Theatre in San Francisco. This devotion has always worked in his favor in terms of enhancing his reputation as one of the most devoted directors and dramaturges of new plays. 
Works Cited 
“Angeling in America.” Playbill Online (2005). 15 August 2005 <http://www.playbill.com/news/article/print/94420.html>.

Brantley, Ben. "One Woman's Quest, Fraught with Cultural Land Mines." Rev. of Homebody/Kabul, by Tony Kushner. New York Theatre Workshop. New York. The New York Times: 20 December 2001.

Brantley, Ben. "Puppets Mine Unexpected Emotional Territory.” Rev. of The Long Christmas Ride Home, by Paula Vogel. Trinity Repertory Company. The Lederer Theatre Center: New York. The New York Times. 10 June 2003. Byrne, Terry. “'Ambition' fulfills its promise.” Rev. of Ambition Facing West, by Anthony Clarvoe. Trinity Repertory Company. Providence, Rhode Island. Boston Herald. 25 April 1997: S13

Clarvoe, Anthony. Ambition Facing West. New York: Broadway Play Publishing, 2003. Clarvoe, Anthony. Ambition Facing West. Draft Material (Unpublished). New York: Writers and Artists Agency, 1996.

Clay, Carolyn. "Fusion Feast: Vogel's Ride is well worth taking." Rev. of The Long Christmas Ride Home. Trinity Repertory Company. Providence, Rhode Island. The Providence Phoenix. 20 May 2003.

Clay, Carolyn. "Mother of Invention: The Ruby Sunrise maps the dawn of TV." Rev. of The Ruby Sunrise, by Rinne Groff. Trinity Repertory Company. Providence, Rhode Island. The Providence Phoenix. 20 May 2004. 
Clay, Carolyn. "Prophet and loss: Tony Kushner's prescient journey to Kabul." Rev. of Homebody/Kabul, by Tony Kushner. Trinity Repertory Company. Providence, Rhode Island. The Providence Phoenix. 29 March 2002: 10. Eustis, Oskar. “Going Public: A New Vision for America’s Flagship Theater Pays Homage to the Past." The Village Voice (2005). 25 August 2005 <http://www.villagevoice.com/theater/0534,eustis,67095,11.html>.

Feingold, Michael. "Rinne Groff's Ruby Sunrise: Reinventing Television for the Sake of World Peace." Rev. of The Ruby Sunrise, by Rinne Groff. The Public Theater. New York. The Village Voice. 22 November 2005. <http://www.villagevoice.com/theater/0547,feingold,70257,11.html>. Accessed November 25, 2005.

Gale, William K. “Too much ‘Ambition'?” Rev. of Ambition Facing West, by Anthony Clarvoe. Trinity Repertory Company. Providence, Rhode Island. Providence Journal-Bulletin. 25 April 1997: E1

Gray, Channing. "A finely tuned portrait of television's early days." Rev. of The Ruby Sunrise, by Rinne Groff. Trinity Repertory Company. Providence, Rhode Island. The Providence Journal. 21 May 2004: E1, E4

Gray, Channing. “Trinity Rep's Homebody dazzles; But Kushner's ambitious epic is also dizzying.” Rev. of Homebody/Kabul, by Tony Kushner. Trinity Repertory Company. Providence, Rhode Island. The Providence Journal. 22 March 2002: E-1, E-4.

Groff, Rinne. The Ruby Sunrise. Draft Material (Unpublished). 2003. 
Groff, Rinne. The Ruby Sunrise. Performance Script (Unpublished). 2004.

Hurwitt, Robert. "Oskar Eustis Began in Radical Theatre, Moved on to the Eureka, Now He’s To Take Over N.Y. Public.” San Francisco Gate. 30 November 2004. <http://www.sfgate.com>. Accessed October 29, 2005.

Isherwood, Charles. "Dreams, Compromise and a Talking Box." Rev. of The Ruby

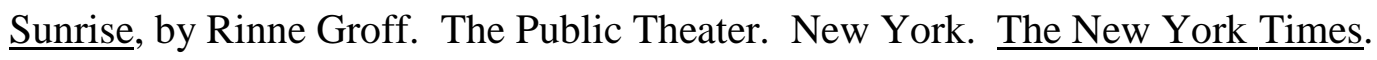
17 November 2005. <http://theater2.nytimes.com/2005/11/17/theater/reviews/17ruby.html?ex= $1135227600 \&$ en=6b975fdc8642feff \&ei=5070>. Accessed November 17, 2005.

Kushner, Tony. “An Afterword.” Homebody/Kabul. Revised Version. New York: Theatre Communications Group, 2004.

Kushner, Tony. Homebody/Kabul. $1^{\text {st }}$ Draft (Unpublished). New York: Joyce Ketay (Agent), 2000.

Kushner, Tony. Homebody/Kabul. Revised Version. New York: Theatre Communications Group, 2004.

Marcus, Abraham. "Taliban." World Book Online Reference Center. 2006. World Book Encyclopedia. 8 Feb. 2006. <http://www.worldbookonline.com/wb/Article?id=ar749759>. Program for Ambition Facing West, by Anthony Clarvoe. Dir. Oskar Eustis. Trinity Repertory Company, Providence, Rhode Island. 1997. 
Program for Homebody/Kabul, by Tony Kushner. Dir. Oskar Eustis. Trinity Repertory Company, Providence, Rhode Island. 15 Mar.-21 Apr. 2002 Program for The Long Christmas Ride Home, by Paula Vogel. Dir. Oskar Eustis.

Trinity Rep Repertory Company, Providence, Rhode Island. 16 May-29 Jun. 2003.

Program for The Ruby Sunrise, by Rinne Groff. Dir. Oskar Eustis. Trinity Repertory Company, Providence, Rhode Island. 14 May-20 June 2004.

Rizzo, Frank. Rev. of The Ruby Sunrise, by Rinne Groff. Trinity Repertory Company. Providence, Rhode Island. Daily Variety. 19 May 2004.

Rooney, David. Rev. of The Ruby Sunrise, by Rinne Groff. The Public Theater. New York. Daily Variety. 22 November 2005. <http://www.variety.com/review/VE1117928880?categoryid=33\&cs=1\&q uery $=\% 27$ ruby + and + sunrise $\% 27 \&$ display $=\% 27$ ruby + sunrise $\% 27>$. Accessed November 29, 2005.

The Ruby Sunrise. By Rinne Groff. Dir. Oskar Eustis. Perf. Marin Ireland, Richard Masur, Anne Scurria. The Public Theater. New York. 23 November 2005.

Siegel, Ed. “In Trinity Rep's stunning 'Ride,' East meets West.” Rev. of The Long Christmas Ride Home, by Paula Vogel. Trinity Repertory Company. Providence, Rhode Island. The Boston Globe. 24 May 2003. 
Siegel, Ed. "Trinity Rep's 'West' fulfills most of its ambitions.” Rev. of Ambition Facing West, by Anthony Clarvoe. Trinity Repertory Company. Providence, Rhode Island. The Boston Globe. 28 April 1997.

Simon, John. "Kabul Hell." Rev. of Homebody/Kabul, by Tony Kushner. New York Theatre Workshop. New York. New York Magazine. 7 January 2002: 60-61. Taylor, Markland. Rev. of Ambition Facing West, by Anthony Clarvoe. Trinity Repertory Company. Providence, Rhode Island. Variety. 23-29 June 1997.

Taylor, Markland. Rev. of The Long Christmas Ride Home, by Paula Vogel. Trinity Repertory Company. Providence, Rhode Island. Daily Variety. 19 June 2003. Vogel, Paula. The Long Christmas Ride Home: A Puppet Play with Actors. New York: Dramatists Play Service, 2004.

Vogel, Paula. The Long Christmas Ride Home. $6^{\text {th }}$ Draft (Unpublished). New York: The Gerth Agency, 2003. 
$\underline{\text { Appendix }}$

World Premieres at Trinity Repertory Company

During the Tenure of Oskar Eustis 


\begin{tabular}{|c|c|c|c|}
\hline Season & Play or Musical & $\begin{array}{c}\text { Playwright, Original } \\
\text { Playwright (if } \\
\text { Applicable), Translator } \\
\text { (if Applicable) } \\
\text { Composer (if } \\
\text { Applicable) }\end{array}$ & $\begin{array}{c}\text { Director/Musical } \\
\text { Director (if Applicable) }\end{array}$ \\
\hline $1994-1995$ & God's Heart & Craig Lucas & Norman Rene \\
\hline 1995-1996 & $\frac{\text { The Return of Don }}{\text { Quixote }}$ & $\begin{array}{c}\text { Adapted by Kyra } \\
\text { Obolensky }\end{array}$ & Brian Kulick \\
\hline 1996-1997 & The Mineola Twins & Paula Vogel & Molly Smith \\
\hline 1996-1997 & Ambition Facing West & Anthony Clarvoe & Oskar Eustis \\
\hline 1997-1998 & Peer Gynt & $\begin{array}{l}\text { Henrik Ibsen, adapted } \\
\text { by David Henry Hwang } \\
\text { and Stipan Müller }\end{array}$ & Stipan Müller \\
\hline 1997-1998 & A Girl's Life & Kathleen Tolan & Barry Edelstein \\
\hline 1997-1998 & $\frac{\text { The Chemistry of }}{\text { Change }}$ & Marlane Meyer & Constance Grappo \\
\hline 1998-1999 & $\frac{\text { A Preface to the Alien }}{\text { Garden }}$ & Robert Alexander & $\begin{array}{l}\text { Edris Cooper- } \\
\text { Anifowoshe }\end{array}$ \\
\hline $1999-2000$ & $\underline{\text { Fall }}$ & Bridget Carpenter & Neal Baron \\
\hline $2000-2001$ & $\underline{\text { Henry Flamethrowa }}$ & John Belluso & Lisa Peterson \\
\hline $2000-2001$ & $\underline{\text { The New England Sonata }}$ & Eliza Anderson & Amanda Dehnert \\
\hline 2001-2002 & Homebody/Kabul & Tony Kushner & Oskar Eustis \\
\hline $2002-2003$ & $\frac{\text { The Long Christmas }}{\text { Ride Home }}$ & Paula Vogel & Oskar Eustis \\
\hline 2003-2004 & The Ruby Sunrise & Rinne Groff & Oskar Eustis \\
\hline 2004-2005 & The Moliere Impromptu & $\begin{array}{l}\text { Christopher Bayes, } \\
\text { adapted and translated } \\
\text { by Rinne Groff }\end{array}$ & Christopher Bayes \\
\hline 2004-2005 & $\frac{\text { Charles Strouse's You }}{\underline{\text { Never Know }}}$ & $\begin{array}{c}\text { Music and lyrics by } \\
\text { Charles Strouse; Book } \\
\text { by Charles Strouse and } \\
\text { Rinne Groff }\end{array}$ & Amanda Dehnert \\
\hline
\end{tabular}

